\title{
Theoretical and methodological approaches to the study of information need in the context of the impact of new information and communications technologies on the communication of parliamentary information
}

\section{Rita Marcella, Graeme Baxter and Nick Moore}

\author{
Rita Marcella, The University of Newcastle at Northumbria, rita.marcella@unn.ac.uk \\ Graeme Baxter, The Robert Gordon University, g.baxter@rgu.ac.uk
}

Nick Moore, Acumen, nick@acumenuk.co.uk

\begin{abstract}
This paper discusses critically the theoretical and methodological background to an Economic and Social Research Council (ESRC) research project designed to investigate the impact of Information and Communications Technologies (ICTs) on the communication of parliamentary and legislative information to the general public or citizen. It sets out the context of the study in terms of the changes in governance, resulting from devolution and, via a wide ranging literature review, describes the ways in which the authors' research approach has developed. The design of the project methodology, that of an interactive online interview executed via a roadshow, is also described.
\end{abstract}

\section{Introduction}

This paper describes the ideas and methodological approaches underpinning an Economic and Social Research Council (ESRC) project, currently being undertaken by the authors, which examines the impact of new technology on the communication of parliamentary information to the general public. In addition to setting the current scene in terms of parliamentary information and communication, the paper explores the kinds of questions that theorists have set out to answer in relation to information seeking behaviour, and outlines the ways in which such research has developed. In developing their ideas for this new project, the present research team were motivated by a desire to apply a data collection instrument that was best suited to their theoretical stance.

The project is particularly significant in that it takes place at a time of dramatic constitutional change in the United Kingdom: Scotland has elected its first Parliament for almost 300 years, with primary legislation and tax varying powers; Wales has established its own National 
Assembly, albeit less powerful than the Scottish Parliament; while the New Northern Ireland Assembly ended over 20 years of direct rule from Westminster. These three new legislatures are currently developing their library and public information services in order that they meet the information needs of their elected members and the general public. They are coming into operation at a time when concepts of informed citizenship and the role of information in democratic processes are being re-shaped with the emergence of information-based societies. The current research project will consist of a comparative study of the three services, together with the traditional parliamentary information service at Westminster, assessing the information produced by each and its relevance to the community at large, and developing a model of parliamentary information provision to the public. The research is focusing upon the appropriateness, approachability and utility of Information and Communications Technologies (ICTs) in delivering parliamentary information to the general public and in encouraging the public to interact with government. The project team are observing and gathering comparative data on end-user behaviour in the application and use of ICTs, in particular in the navigation around web-based technologies which enable access to public information. It seeks to gain insight into the behaviour of the information user in the context of the use of information about government.

This paper will outline the background to the project and review the theoretical and methodological approaches that underpin it. It is impossible within the paper's scope to review all of the significant researchers in the field of information need and use: the paper will, therefore, be limited to those that have been most influential in terms of the authors' work.

\section{Background to the Project in the United Kingdom}

The research is taking place during the formative period of the three new devolved legislatures in the UK. The Government's Joint Consultative Committee with the Liberal Democrat Party (Liberal Democrat Party, 1998) described the four key principles of this new, devolved approach as:

- the decentralisation of power from Westminster;

- the strengthening of the rights of every citizen through legislation;

- making government more open and accountable to the people; and

- making institutions more representative and accountable by reforming Parliament, cleaning up the financing of political parties and other measures. 
The formation of the Scottish Parliament, in particular, is seen as heralding a new, more transparent style of government:

'...the establishment of the Scottish Parliament offers the opportunity to put in place a new sort of democracy in Scotland... an open, accessible Parliament; a Parliament where power is shared with the people; where people are encouraged to participate in the policy process which affects all our lives; an accountable, visible Parliament...' (Consultative Steering Group on the Scottish Parliament, 1998a).

In creating their public information services, the devolved administrations have drawn upon the experiences of the traditional UK Parliament in Westminster. Established in 1978, the House of Commons Information Office, part of the House of Commons Library, dealt with almost 114,000 enquiries from the public in 1999-2000 (House of Commons Information Office, 2000); while the more recently established (in 1998) House of Lords equivalent dealt with around 28,000 enquiries during the same period (House of Lords, 2000). Since 1996, the UK Parliament has had its own website providing access to a wide range of Commons and Lords publications, including Hansard, Private and Public Bills, Acts, Statutory Instruments, Select Committee Reports, and Minutes and Order Papers (United Kingdom Parliament, 2001).

In 1998, the Consultative Steering Group (CSG) on the Scottish Parliament developed a draft Information Strategy, based on the Swedish Public Information Strategy, which stated that:

'The Scottish Parliament is committed to providing an Information Service aimed at ensuring that the Parliament is as open, accessible and participative as possible. Only well-informed citizens can maximise the opportunities which this presents for individuals and organisations to contribute to the democratic process.' (CSG, 1998b).

To this end, the Scottish Parliament has established a Public Information Service, based in Edinburgh. Part of the Information Systems section, which is a subdivision of the Communications Directorate, the service consists of an enquiry unit, an education service for schools, and a visitor centre and shop. In the calendar year 2000, the service dealt with just under 40,000 visitors, almost 88,000 telephone calls, and over 3,700 more detailed enquiries on various aspects of the Scottish Parliament (Scottish Parliament Public Information Service, 2001). The Scottish Parliament website, maintained by a team within the Communications Directorate, contains a wide range of publicly accessible parliamentary information, including 
the Official Report (the record of the proceedings of the Parliament and its committees), Bills, Petitions, research briefings, news releases and a weekly newsletter What's Happening in the Scottish Parliament (WHISP); a webcasting service also broadcasts events from the Parliament's Chamber and Committee Rooms (Scottish Parliament, 2001).

Meanwhile, the Scottish Parliament's internal information service, designed to meet the needs of Members of the Scottish Parliament (MSPs), their staff and Parliament staff, has been titled the Scottish Parliament Information Centre (SPICe) and also forms part of the Communications Directorate. Significantly, SPICe has appointed a Library Liaison Officer, whose main function is to foster good relations with other libraries, and has established a network of 76 'Partner Libraries' (one in each of the 73 parliamentary constituencies, plus an additional three in the Highlands and Islands) to act as a focal point within local communities for information about the Parliament (Anderson, 2000). SPICe currently offers three key services to the Partner Libraries. Firstly, it supplies, free of charge, a range of Scottish Parliament publications to each library. Secondly, it provides support to library staff in answering enquiries about the Parliament received from the public (based on anecdotal evidence only, the number of enquiries received by libraries so far has been low, but is slowly increasing). Thirdly, SPICe offers training to Partner Library staff in the use of Scottish parliamentary documentation, with the aim of developing their information handling and information seeking skills. SPICe is also encouraging Partner Libraries to provide Internet access for members of the public, so that they might utilise the Scottish Parliament website. In an unpublished, internal survey in February 2001 (Scottish Parliament Information Centre, 2001) it was established that 60 (78.9\%) of the Partner Libraries currently provide public Internet access; and that, of these, 22 (36.7\%) provide free access. It is also hoped that MSPs will develop close links with Partner Libraries, perhaps using them for constituency surgeries and meetings. By February 2001, however, only 14 (18.4\%) Partner Libraries had held MSP surgeries, while just 5 (6.6\%) were aware of users having been referred to them by MSPs' constituency offices.

The National Assembly for Wales, meanwhile, has established a Public Information and Education Service, based in Cardiff. Part of the Presiding Office, the service comprises: a visits team, responsible for individual and group visits to the Assembly; a special projects team, responsible for answering enquiries from the public (currently at a rate of around 200 each week), producing publications and providing an Assembly presence at major public events throughout Wales; and an education team, which organises an educational programme for Welsh schools. A new visitor and education centre, situated at the Pierhead, Cardiff Bay, opened in Spring 2001. Like its Scottish Parliament counterpart, the Welsh Assembly's 
website provides public access to a range of material, including the Record of Proceedings (the official record of what was said in the Chamber), agendas and minutes, annual reports, consultation papers and press releases (National Assembly for Wales, 2001a). These materials are available in both English and Welsh.

Supported by the National Assembly for Wales Library and a Publications Centre located in the Pierhead building, the Assembly has adopted the Scottish Parliament's Partner Library concept to create Information Link, a network of 41 designated public libraries throughout Wales, approximately one in each of the 40 Assembly constituencies. Each library receives one paper copy of every Assembly publication and has to retain it for a minimum of 6 months. Libraries are obliged to provide 'free and open access' to Assembly information in both printed and (where available) electronic form, and to provide it in 'a designated area' within the library (National Assembly for Wales, 2000). There are currently no plans for Information Link libraries to establish links with elected Assembly Members, or to host constituency surgeries and meetings. To date, the Assembly has gathered no details (not even of an anecdotal nature) on the level of public use of the libraries' Assembly materials and/or the number and type of Assembly-related enquiries received at these libraries.

Due to delays in the peace process, the information services of the Northern Ireland Assembly are not as advanced as those of its Scottish and Welsh counterparts, although the wish for an 'open, transparent, accessible and accountable' Assembly with a 'high standard of information and communication systems' was identified at an early stage (Fee, 1999). The Assembly's Public Information Office is currently a 'hybrid' office, reporting both to the Keeper of the House and to the Director of Research and Information. When the Assembly is sitting, it answers around 20-25 enquiries each day from the general public and a further 1012 enquiries from the press. An education programme for schools is in the early stages of preparation. The Assembly website, however, has recently been upgraded; it contains documents such as the Official Report, committee reports, minutes of proceedings and forthcoming business, and it also provides live broadcasts of Assembly plenary sessions (Northern Ireland Assembly, 2001).

The current research is also timely in that it coincides with a number of major developments within the UK in terms of public access to parliamentary and other government information. The UK's much delayed Freedom of Information Act finally received Royal Assent in November 2000 (Great Britain: House of Commons, 2000), although it is not expected to come into force until Summer 2002. Criticised initially as 'a major retreat' from the Government's original white paper (Campaign for Freedom of Information, 1999), 
subsequent revisions made to the bill as it passed through Parliament have failed to silence the critics. This is in contrast to the situation in local government, where the Local Government (Access to Information) Act 1985 has required local authorities to be much more pro-active in the disclosure of information (Steele, 1995).

In July 1999, the Scottish Executive introduced a non-statutory Code of Practice on Access to Scottish Executive Information (Scottish Executive 1999), but plans to replace this with a Freedom of Information regime. A draft bill was published in March 2001 (Scottish Executive, 2001) and has been welcomed, but with reservations (Campaign for Freedom of Information, 2001; Scottish Library and Information Council and Scottish Library Association, 2001). The National Assembly for Wales has also implemented a Code of Practice on Public Access to Information, now in its second edition (National Assembly for Wales, 2001b); while in February 2000, David Trimble, the then First Minister of the Northern Ireland Assembly, indicated that the Executive Committee would discuss the introduction of separate Freedom of Information legislation for the Province (Trimble, 2000).

In March 1999, the UK Government published its white paper on Crown Copyright (Cabinet Office, 1999), which listed a number of categories of material from which Crown Copyright has been waived and which announced the establishment of an electronic Information Asset Register - inforoute (Her Majesty's Stationery Office, 2001) - which will act as a gateway and central information point to direct people to government information and materials. Additional changes to Crown Copyright currently being considered have been outlined by Picton (2001).

The UK Government has recently re-emphasised its commitment to what it terms 'information age government', and has set a target that all dealings with government will be deliverable electronically by 2005 (Blair, 2000). Its strategic framework for e-government was published in April 2000 (Cabinet Office, 2000). Using the People's Network infrastructure (30,000 publicly accessible Internet terminals in public libraries across the UK by the end of 2002 (Batt, 2000)) as a core component, it plans to establish up to 3,500 UK Online Centres in public libraries (in England in the first instance), with each one having the potential to act as a centre for e-government. A key feature of the UK Online Centre initiative is the provision of the UK Online citizen portal, which provides a single online point of entry to government information services, including parliamentary and devolved assembly resources (UK Online, 2001). 
The Scottish Executive published its own draft e-government framework in December 2000 (Scottish Executive, 2000a); while a target parallel to that set by the UK Government - that all devolved public services in Scotland be available online by 2005 - has also been established (Dewar, 2000). A Scottish government portal, linked closely with the UK Online citizen portal, is to be developed.

Research conducted on behalf of the Cabinet Office Central IT Unit indicated that 29\% of the UK public would be very likely to use electronic government services, while an additional $44 \%$ would be quite likely to use them (Cabinet Office, 1998). The Parliamentary Office of Science and Technology (1998) reported upon the potential for electronic interchange of information between government and the electorate; while in 1999, the Hansard Society launched its e-democracy programme, which explores inclusive ways of involving citizens in the parliamentary process. Ecclestone (1998) provides an excellent critical examination of the UK Government's performance in making public information available on the Internet, in particular in evaluating the quality of information presently provided and in the enabling of feedback from the public on government policy making and initiatives.

The establishment of the Scottish Parliament is seen as providing an ideal opportunity to develop understanding of the impact of ICTs upon social behaviour in relation to the public's interaction with government. The Advisory Committee on Telematics for the Scottish Parliament (1997) recommended the creation of an open parliament based upon state of the art ICTs: 'the creation of a Scottish Parliament, based on the principles of openness and accountability to the people, offers the opportunity to utilise modern applications of telematics to realise those principles'.

The Committee also suggested that there be online experimentation with citizens' panels, citizens' inquiries, deliberative polling groups, MSPs' surgeries, fora and town meetings. This led Coleman (1999) to state that 'if just some of these initiatives are followed through in the first few years of the new parliament, it will stand as a model of communicative democracy and will surely set an example for legislative assemblies across the world'. An Expert Panel on Information and Communications Technologies (CSG, 1998c) recommended that the Scottish Parliament should focus upon how ICTs may assist democratic participation, including governance and citizen participation, and the contribution that emerging technologies can make in enabling greater openness and accessibility. The Panel recommended that the Scottish Parliament should 'aspire to be an example of best practice in parliamentary information systems', while being aware of the danger of exclusion for 
marginalised, disillusioned and less educated groups, on the basis of information, economic and technology deficits.

In May 2000, the Digital Scotland Task Force, a Scottish Executive initiative which aims to ensure that Scotland obtains and retains maximum economic and social advantage from ICTs, produced a report which stated that 'technology creates opportunities for more citizens to become more actively involved in public consultation and in the democratic process generally'. It recommended that the Scottish Executive provide such opportunities through the provision of online consultation (and online feedback on consultation), online opinion sampling, e-mail access to officials and elected members, and electronic voting (Digital Scotland Task Force, 2000). In its response, of September 2000, the Scottish Executive stated that 'concrete action is being taken to enhance its capability in online consultation', and that it is also to consider implementing electronic voting pilots (Scottish Executive, 2000b).

\section{Theoretical and methodological approaches}

While what is required is an extended monograph on the subject, this paper will seek in a necessarily superficial manner to review some of the ideas that have fed into the authors' study. It is worth noting that the research also builds upon previous work conducted by the present authors. Marcella and Baxter (1998, 1999a, 1999b \& 2000) investigated information need and information seeking behaviour in relation to citizenship information (i.e. information produced by or about government and public sector organisations); while Moore (1998) explored people's attitudes to public services, establishing that the better informed people felt, the greater was the level of satisfaction they expressed with the services. The main elements of the citizenship information project were two large-scale, nation-wide surveys of the citizenship information needs and information seeking behaviour of the British public. The first of these was a questionnaire-based survey of just under 1,300 individuals. This questionnaire was distributed in public libraries, Citizens Advice Bureaux (CABx) and other generalist information and advice agencies throughout the UK, and was designed to gather some preliminary data on the public's use of and need for citizenship information. The second survey was designed to gather more in-depth, qualitative and extended responses, and consisted of personal doorstep interviews with almost 900 citizens, with the interviewees being selected using the random walk sample method. These interviews were carried out by undergraduate and postgraduate librarianship and information studies students. The interview schedule paid particular attention to national and local government issues and to 'survival 
information' (i.e. information to help people overcome the problems that occur in day-to-day life), and also sought to investigate the concept of the well-informed and active citizen.

Many writers comment on the lack of theory in studies of information seeking, although it may be that the problem is less a lack of theory than the lack of a good road map guiding us through the theory. Menzel (1960), Paisley (1965) and Ford (1977) argue that the progress towards a theoretical understanding of information need has been slow. As early as 1965, Fishenden (1965) was moved to call for the broadening of the base of research from scientists to other information users. Ford also describes a 'general lack of theory and an equal lack of definition of concepts' (Ford, 1973). He criticises the lack of investigation of need and the focus upon the evidence of use via statistics in much of the earlier work that had been carried out, defining information need as 'an awareness of "not knowing" - or some conceptual incongruity in which the learner's cognitive structure is not adequate to the task'. Ford calls for a more complete understanding of the user in terms of the way in which information will be used to add to cognitive understanding and also of the user's psychological motivations for acquiring information. He criticises the over concentration on topics and subjects in earlier information needs research. Wilson's excellent review (1994) of research into information needs and uses considers critically the most significant research to have taken place over a fifty year period, from what he describes as an early emphasis on information systems use to a later more person-oriented approach that evolved in the 1980s.

Dervin (1977) recognises similar limitations in existing research, arguing that the majority of information studies research has focused upon the library and its activities and has considered the user only in this context: she advocates research questions that are 'based upon a set of pervasive and internally consistent assumptions about the nature of people and how they cope and the nature of information and how it helps'. She recommends a sense-making approach in 'a programmatic effort to study how people construct sense of their worlds and, in particular, how they construct information needs and uses for information in the process of sense making'. Significant elements or life situations in her model are: decisions; problems; worries; and comprehendings. The six-stage model includes initiation, selection, exploration, formulation, collection and presentation, and Dervin recommends that researchers should go beyond the process of information seeking to consider how users learn from the information they acquire, by examining the role of intervention (whether human or system) via collaboration and constructing meaning from the information acquired by users acting and reflecting, feeling and formulating, predicting and choosing and interpreting and creating. She argues that information is only an input to being informed and that information only has meaning in relation to what the person already knows. This work is further extended by that of Saracevic, Mokros and $\mathrm{Su}$ 
(1990) in developing a model of information value processes and in consideration of the interaction between information seekers and intermediaries, via information consolidation. Saracevic (1999) typifies information need research as emerging from the idea of 'relevance' in terms of the need to develop a better understanding of the manner in which information relates to individuals' lives.

The present authors aim to investigate information seeking in a context potentially far removed from the library, and their methodology has been partially determined by that need to get as close to the user's everyday life as possible. This closeness is attempted both on the physical and the personal level in that a better understanding of the ways in which information relates to respondents' real lives is sought through a methodology that goes to the respondent at home, work or in social situations. This is in line with Wilson who claims that information need research should focus upon 'uncovering the facts of the everyday life of the people being investigated ... to understand the needs that exist which press the individual towards information-seeking behaviour [and that it is] ... by better understanding those needs we are better able to understand what meaning information has in the everyday life of people' (Wilson, 1981). He (Wilson, 1999) has developed a number of increasingly complex models of information behaviour and proposes that the basis of such a model is a problem, or state of uncertainty, that impels individuals to engage in often successive searching, where the solution to the problem becomes the goal and individuals engage in goal-seeking behaviour.

Marcella and Baxter, in the design of the citizenship information surveys, included questions which sought to explore this link between a problem and information need. While this was often useful, it did not always enable respondents to recollect an example of information need. Other approaches which ask about occasions of information need in other ways are likely to be equally useful. In fact a phalanx of methods should be adopted in a complementary fashion, for as Audunson (1999) concludes, 'real life information seeking exhibits traits that cannot be understood if information seeking is seen as an instrument to solve problems or build bridges over gaps'. Taylor (1987) has developed a framework for investigation of different information use contexts which may be useful: however, the authors recommend that a theoretical model of ways of conceptualising information need should be developed drawing upon the body of existing research and the experience of information intermediaries. Belkin (1984) considers the dynamic interaction between the user, the information resource and the intermediary and the ways in which they build and use models of each other, in terms of the intermediary's role in helping the user to clarify a problem and reach a resolution, via the construction of a cognitive model. Vakkari's work (1999) focuses upon the ways in which information seeking is inextricably linked to the user's task and concludes that 'prior knowledge about a task by an 
actor is a major factor in determining what information is needed for its accomplishment'. All of these suggest ways in which questions about information need might be formulated, and in devising interview or questionnaire schedules it is worth reviewing such theorists to determine which questions should he asked and how they should be formulated.

A number of researchers have advocated an open approach to information needs research. Beal (1979), for example, argues that 'what information we believe people ought to know is a value judgement, and a political one, made up of the views we hold of people's lives'. It is certainly imperative that researchers should make a genuine open and unbiased effort to allow respondents to express freely their actual need. This argument reinforces the value of a phenomenological approach. However, the authors would argue that in too open an approach, little meaningful data will be collected and soundly constructed active questioning is preferable. Dervin and Wilson tend towards the phenomenological, while acknowledging the significance of the broader context of the life situation of the individual and the context of needs other than the cognitive. Huber (1983) likewise concludes that 'the study of cognitive style ... has not been fruitful, although he does suggest that if better instruments for the assessment of cognitive styles were developed, they could be useful in establishing the natural propensities of information users. Kuhlthau (1991) emphasises the importance of exploring the feelings, thoughts and actions associated with the various stages of the information search process from the user's perspective, together with other concepts that emerge from her information seeking research such as 'uncertainty', 'complexity' and 'the concept of enough' (Kuhlthau, 1999). The present authors recognise the validity of all of these as factors impacting upon information need and information seeking and have tried to develop a data collection tool that would be sufficiently open to allow such aspects to be explored.

There are a number of researchers, who have sought to develop theories about the characteristics of the information seeker from Shutz (1946) and Dervin (1976) onwards. In the first of these, Shutz categorised individuals into three groups: the expert; the well-informed citizen; and the man on the street. Others have gone beyond this simple yet useful typology. Bystrom (1999), for example, seeks to map and evaluate theories about the individuals who engage in information seeking in order to develop a better understanding of what she terms the 'doer' in information behaviour research. She identifies three major categories of 'doer': the Platonian Man; the Debater; and the Chessman. Others have also renamed the information actor, suggesting that 'user' as a term may have a negative connotation. Palmer (1991), for example, identified five categories: non-seekers of information to whom information was a problem; lone, wide-rangers who scanned within and outwith their subject field; unsettled, selfconscious seekers, who are relatively new to information seeking; confident collectors, who had 
abandoned regular information seeking but held developed collections; and hunters who maintained regular routines to make sure that nothing relevant escaped them. Wilson and Walsh (1996) identify four patterns of information acquisition: passive attention when information seeking is not intended; passive search when one type of behaviour incidentally results in the acquisition of information; active search; and ongoing search when efforts are made periodically to enhance and update information already held.

Wilson (1981) relates information need to the areas of human need as categorised by psychologists: physiological needs; affective needs; and cognitive needs. In their review of research into information behaviours, Wilson and Walsh (1996) seek to synthesise work in a variety of disciplines, such as psychology, health communications, decision making and information systems design, in order to determine whether useful models of information behaviour may be developed. They identify certain categories of need, such as: the need for new information; the need to elucidate information held; the need to confirm information held; the need to elucidate beliefs and values held; and the need to confirm beliefs and values held. Stress and coping theory are also suggested as providing effective ways of exploring information need, where coping is defined as '... cognitive and behavioural effects to master, reduce or tolerate the internal and external demands that are being created by stressful situations' (Folkman, 1984).

While such theories and typologies are interesting and thought provoking, suggesting numerous research questions, they lie outwith the scope of the present project, which does not seek to categorise in advance but may do so in light of the results of the exercise, if differing patterns of information approach observedly emerge.

There is a significant body of research into the information needs of potentially marginalised groups and of particular localities. These also influenced the present authors, as their project seeks in particular to target potentially marginalised groups in the community. It was, therefore, interesting to examine how others had tackled this problem. Bruce, McKennel and Walker (1991) surveyed the needs of the visually impaired, while Tinker, McCreadie and Salvage (1994) carried out an exploratory study of elderly people. The Central Office of Information Informability Unit (1994) has produced guidelines on communication techniques and the types of media which can facilitate information access for people with a disability; while the National Working Party on Social Inclusion (1997) identified women, ethnic groups, older people and rural communities as those groups most at risk from exclusion in the Information Society. 
With regard to studies of localities, the most influential study was that carried out in Baltimore (often referred to as the Baltimore Study), by Warner, Murray and Palmour (1973). This study is still regarded as 'a benchmark for large-scale investigations of this kind' (Wilson, 1994). Its methodology formed the basis for a major survey of the public's information needs carried out in 1977 by the Centre for Research on User Studies in Sheffield (Beal, 1979), which found that the public required support and help in accessing and using information. The results of such studies tend to show low levels of awareness of information services, an inability or unwillingness amongst respondents to articulate information needs and a low level of understanding amongst information professionals of the problems faced by residents. The Baltimore Study indicates the significance of investigating information need from the perspective of the ordinary life and work experiences of respondents and of taking a problem (rather than information) based approach. It was highly influential in the development of survey instruments as part of Marcella and Baxter's earlier work (Marcella \& Baxter, 1999a, $1999 \mathrm{~b}$ and 2000).

Research into barriers to information seeking has identified various factors that may impede the initiation of information seeking. The present authors are very interested in the ways in which particular groups may be affected by such hypothesised barriers. Their earlier research would suggest that it is not only marginalised groups which face such barriers. Bettman and Pack (1977) suggest that highly knowledgeable people may feel less need to seek information. Radecki and Jaccard (1995) find that individuals are also influenced by their awareness of the level of knowledge of others and the importance of the topic. Other studies have found that information seeking decreases with age or is greater amongst women with children (Feick, Herrmann and Warland, 1986). Wilson identifies personal, interpersonal and environmental or social barriers to information seeking, while the Baltimore Study (Warner, Murray and Palmour, 1973) extends these to include psychological, intellectual, institutional and societal barriers. Other barriers - such as cost, effort required, access, demographic and socio-economic factors and the credibility of sources - might be hypothesised and the authors were keen to explore these further in their own research.

In 1976, Dervin argued that 'the clearest generalisation which emerges from this discussion is that huge gaps exist in the knowledge base relating to average citizens and their information needs' (Dervin, 1976): such gaps exist today and the present authors hope that their work has contributed and will continue to contribute to the attempt to build bridges. They believe, with Dervin (1997) and Kuhlthau (1999) that context is a necessary source of meaning in studies of information seeking, need and use. There are many contexts still be explored in sufficient depth for us to achieve a thorough understanding of their significance and while we continue to 
explore these specific contexts, we add to our knowledge holistically for as Dervin (1997) argues, context helps us both to understand that which is situation specific and those aspects of information seeking and use that represent general characteristics of behaviours.

Broadly the authors' research has moved from a positivist to a phenomenological theoretical perspective. Early work (Marcella and Baxter, 1999a, 1999b and 2000) focused largely upon the use of quantitative and qualitative methodologies via large-scale surveys that underpinned the desired research outcomes in order to achieve objective generalisations about human behaviour in society. Through the collection of empirical data, it was hoped that rational explanations of human behaviour would be uncovered and recommendations could be made. However, latterly the research has moved increasingly towards a phenomenological view, which seeks to interpret how people construe or make sense of the world in different ways and which acknowledges that individual experience is of necessity subjective. Such an approach constructs a vision of how people make sense of the world from their myriad individual vantage points. This approach is typically used to construct theory, with an understanding of how specific recommendations have different implications for different people. It is felt that this epistemology is likely to be particularly fruitful in understanding exclusion from the social world, although its value is by no means limited to that application. With this move towards phenomenological research there has been a parallel increasing emphasis on genuinely openended exploration and questioning of research subjects, where the results are not biased by the researcher's predetermined agenda.

Methodologically, information need research in the public domain has equally moved from an early reliance on positivist surveys to the use of diverse methodologies in a mix of quantitative and qualitative research tools, enabling a more holistic view to emerge from the researcher getting 'close to the data, thereby developing the analytical, conceptual and categorical components of explanation from the data itself' (Weingand, 1993). Weingand describes the move towards the borrowing of tools from other research disciplines, such as the ethnographic techniques of anthropology and the phenomenological influences of sociology which have been particularly influential in information need research. Early studies by Line (1967) and Lipetz (1970) review the methodological problems associated with the investigation of users' information needs and use. Line (1971) argues that observation in conjunction with questionnaire and interview are necessary in order to minimise the serious deficiencies associated with each individually. The influential Baltimore study was based upon an interview schedule, which was rigorously tested and applied (Warner, Murray and Palmour, 1973). However, Price (1984) argues against the use of questionnaires and interviews because these tools tend to reveal what the user thinks and not the actualities of behaviour: however, 
observation can only be carried out with relatively small samples and it is often not possible to produce generalisable and analysable results from observation alone. The INISS Project (Wilson and Streatfield, 1977; Wilson, Streatfield and Mullings, 1979; Streatfield and Wilson, 1982), in a reaction against the 'relative sterility of survey based research', was conceived as a qualitative programme using observation and in-depth qualitative interviewing coupled with a participative research mode in the action phase, allowing triangulation of data. Sturges and Chimseu (1996) also justify the use of qualitative methodologies, despite acknowledging the fact that these tend to be complex, time consuming and aimed at generating theory. They advocate a mix of quantitative and qualitative tools, steering a middle course between the superficiality of questionnaires and the total immersion of the anthropologist in the society to be studied. In their use of triangulation, they combine interdisciplinary approaches, attain flexibility and use indigenous knowledge from the perspective of the community under investigation, in examining the information chain between the providers of information, intermediaries and the citizens that are the intended users of the information.

More recently rigorous work has been based upon both questionnaire (Horner and Thirlwall, 1989, and Hallmark, 1994) and on interviews (Bichtler and Ward, 1989; Palmer, 1991; and Hernon and Metoyer-Duran, 1992). Palmer (1991), for example, uses semi-structured in-depth interviews to probe personality, discipline and organisational structure as related to the information seeking behaviour of scientists, using cluster analysis to identify cluster groups amongst respondents. Ellis (1993) and Ellis, Cox and Hall (1993) seek to develop a method of investigation that can be employed across a range of subject groups, building upon a well established approach to theoretical model building in the social sciences which utilises the personal interview to gather data. Eager and Oppenheim (1996) discuss a pilot using an observational method of investigating user information needs, which does not rely upon the use of explicit questions, arguing that this approach overcomes problems associated with identifying less definable but still palpable needs, while proving a robust research tool. The authors acknowledge that the method is less useful where a large group is to be investigated, where there is little predicted similarity in the needs of the group and where need is less frequent. Wilson (1999) has recently piloted a new methodology designed to blend a qualitative approach with the collection of a great deal of quantitative data on various aspects of the information seeking process, by employing a mix of interviewing, tape recordings of searcher/client interactions, logs of online searches and follow up interviews in order to explore uncertainty and its resolution via information seeking, retrieval and use.

Over the past twenty years research has developed into human-computer interaction in information seeking, which encourages the use of a variety of new data collection instruments. 
Transaction log analysis has been used by researchers such as Jansen, Spink and Saracevic (2000) to develop a better understanding of searcher characteristics. A number of authors (Blackshaw and Fischhoff, 1988; Ericsson and Simon, 1993; Nahl and Tenopir, 1996) discuss the use of verbal protocols, or the analysis of 'think-aloud' techniques, to provide a record of online search processes, recording respondents' intentions and decisions in association with an electronic $\log$ of actual search actions. Nicholas (1996) uses a complementary mix of interviews, questionnaires and transaction log analyses. Hert and Marchionini (1997) have explored the users of U.S. statistical websites via online interviews, focus groups, content analysis of email information requests, impressionistic analysis of online comments, usability tests and transaction log analyses.

There has, as we have seen, been a move away from quantitative towards qualitative research in information use studies and towards the complementary use of a range of data collection instruments. In the authors' work there is demonstrated use of a variety of methodological tools that help to build a holistic and informed view of information need and information seeking in a range of communities. There has been a similar move in information behaviour research from a subject and cognitive approach to the person-centred one described by Wilson (1994) and the authors view their more recent work as lying in the latter domain. What much of the published research described above fails to take on board is the communicative aspect of the role of the information provider and this is an aspect which the present authors have sought to explore in relation both to European information (Marcella, Baxter \& Parker, 1997) and to information provided by public sector bodies in the United Kingdom (Marcella \& Baxter, 1998, 1999a, 1999b, 2000; Moore, 1998). Information need must be considered in terms not only of the user and the systems, which exist to enable retrieval of information, but also in terms of the objectives and vision of the information provider. This area is explored most fully in the authors' development of a model of government/public information interchange, which considers the ways in which information is sought, passed and exchanged amongst both parties, each of which may be concurrently a provider and a user of information (Marcella and Baxter, 1998).

The authors would describe their theoretical stance at present as pluralists, who prefer to adopt an interpretive or phenomenological approach where that will support desired research outcomes. They believe that there has been a good deal of relatively sterile debate as to the respective merits of quantitative and qualitative data collection tools and that these, it should be borne in mind, are merely tools that serve the theoretical stance of the researcher which may be positivist or interpretive. Large-scale data collection tools can be designed that utilise both 
quantitative and qualitative techniques in support of what is held to be an interpretive and phenomenological research perspective.

The first stage of the authors' present project, investigating the impact of technology on the communication of parliamentary information to the general public, has consisted of a series of interviews with representatives of the House of Commons and House of Lords Information Offices, and the public information services of the Scottish Parliament, the National Assembly for Wales and the Northern Ireland Assembly. These interviews have gathered detailed data on the objectives and strategies of the services, and on the information access and dissemination activities used and developed by each. They have also gathered information on the number and type of enquiries being made by the general public, and on the public's preferred methods of approaching the information services.

As the second stage of the project, the research team has developed an interactive, electronically assisted interview approach to data collection which is being taken out across the UK as part of a pilot 'roadshow' to societies, institutions and organisations, such as public libraries, community centres, sheltered accommodation and universities, facilitating access to a range of groups in the community. These groups include both those thought to be in danger of social exclusion, such as older people, women, ethnic minority groups and people in rural communities; and those thought likely to be in a position already to make fuller use of ICTs, such as the academic and business communities. It should be noted, though, that due to the less advanced development of the Northern Ireland Assembly public information service, as well as the re-emergence of violent incidents in the area, roadshow events are not being conducted in Northern Ireland.

The interactive, electronically assisted interview constitutes a new form of semi-structured interview methodology and will be thoroughly evaluated as part of the research process. In developing the methodology, the researchers have considered the previous studies of humancomputer interaction in information seeking outlined above. The researchers have developed a tool that, it is anticipated, will provide more in-depth and meaningful data than that produced by the traditional questionnaire survey. The methodology employed also moves beyond that used in computer aided/assisted telephone interviewing (CATI) and computer aided/assisted personal interviewing (CAPI), now common in market research.

The interview involves a structured examination of the UK Parliament, Scottish Parliament or National Assembly for Wales website (the website being examined depends on the geographic location of the roadshow), carried out in a one-to-one situation, with the 
interviewer logging responses to a set of structured questions as the examination proceeds. These include questions on the respondents' demographic characteristics (e.g. age, occupational status, ethnic group, level of educational attainment, etc.), their past need for and use of parliamentary and devolved assembly information, their voting patterns and levels of political participation, and their previous experience in using computers.

Respondents are then allowed a free-form period of undirected information seeking, on the relevant predetermined website, for information on a suggested topic (e.g. child care, hospital waiting lists, public transport policy, student tuition fees) or on a topic of their own choice. These free-form sessions utilise verbal protocol analysis, with the respondents being asked to 'think aloud' as they progress with their search. Finally, respondents are asked a further series of structured questions designed to gauge their feelings on the user-friendliness of the website, the relevance and comprehensibility of the information found, and the likelihood of them revisiting the website in the future.

The interactive electronic interview schedules are being extensively piloted in the online roadshow environment, where a minibus equipped with a laptop computer and mobile data transmission equipment, together with paper-based parliamentary and devolved assembly information resources in support, has ensured a novel outreach approach to members of the public.

Outputs consisting of a transaction log of online activity and audio records of responses to the interview and think-aloud process will be analysed using quantitative and qualitative techniques. Analysis of respondent demographics will determine the effectiveness of the roadshow as a tool for generating a sample that might be deemed representative of at risk groups. Comparisons will be made with other techniques such as random walk and observational techniques in order to evaluate the roadshow approach in terms of the generalisability and meaningfulness of the data collected.

As the project is a pilot, rigorous post execution evaluation is planned in order to test the validity of the data collection tools employed and the generalisibility of results emerging, leading to recommendations for future application of the methodology. It is felt that the project will lead to the establishment, refinement and application of a valid and flexible data collection tool which could be used in a wide range of information and communication research contexts and with a wide variety of target respondents groups. While the data collected would not be deemed significant for and representative of the population as a whole, 
it will provide a sound basis for further development of theories and formulation of hypotheses that may underpin future research in this area

\section{Conclusions}

The project will investigate the robust and effective use of technologies in real human situations and the organisational and social context within which the technology is used. The research will also examine participation and engagement at all levels and in all social groups in the community, particularly in relation to access to ICTs and their use for citizen/government interaction. It will contribute to the understanding of the changing nature of governance in the UK, with particular emphasis being placed on recent devolutionary developments and the new decentralised legislatures' information and communication policies, while seeking to understand how and why knowledge is acquired, shared, communicated, and used, with the aim of fostering a society in which people can contribute and participate fully in its culture, technology and economy.

The research is driven by a desire to find out more about people's behaviour within the context of their everyday lives in the retrieval of, use and application of information and to evaluate the effectiveness of the systems and services that have evolved to meet that need. While seeking specifically to explore the impact of technology upon the communication of parliamentary information, the authors will at all times be conscious of the ultimate user in line with Saracevic (1999) who argues convincingly that 'information science has a strong social and human dimension, above and beyond the technological'. The authors' research also mirrors, in microcosm, the developments that have taken place in research amongst the wider research community into these areas, both in moving from a systems, service and subject-centred approach to one that is user-centred and problem-based, focusing on the life context of the user, and in moving from a potentially superficial quantitative approach to one that is predominantly, although not exclusively, in-depth and qualitative. In particular, the authors believe that the phenomenological study of the individual life situation of the information user and the context of their information behaviour is a very significant area for further exploration. There is also an emphasis on genuinely open-ended exploration and questioning of research subjects.

A number of theories, emerging from the authors' research to date, will be explored as part of the project. These are briefly outlined below:

$\diamond$ That information research should recognise the importance of the concept of information interchange and the different roles of the information 'actor' in holding, providing, 
withholding, accessing and using information. This model would view the information user as interacting with a number of other actors, where all parties are affected by their context or agenda.

$\diamond$ That there is a varying degree of activity and passivity manifest by individuals in differing information behaviour contexts and that each individual may take on different roles and manifest different levels of activity in varying life contexts (in line with the theories of Wilson and Walsh, 1996, and Shutz, 1946).

$\diamond$ That while information seeking and use is most commonly reactive rather than proactive, users tend not to distinguish between the two forms.

$\diamond \quad$ That the motivators for and factors affecting initiation and patterns of information seeking behaviour are complex and relate to variables such as status and social class, gender, age, disability, ethnicity and educational achievement and that, although some of these may appear to be self-evident, the requisite evidence has often not been assembled and results can also be unpredictable and unexpected. Further research is essential into the characteristics that impact upon information seeking behaviour.

$\diamond$ That there is a tendency amongst individuals to exaggerate or idealise both past and, to an even greater extent, future information actions. While it is recognised that attitudes are a very poor predictor of behaviour, the authors' research would suggest that any form of self-reporting may be equally unreliable.

$\diamond \quad$ That people have knowingly suffered disadvantage as a result of inability to access useful information and that they may, additionally and as significantly, have suffered unconscious disadvantage as a result of lack of awareness of the value of information or lack of knowledge of the information resources that exist.

$\diamond$ That young people tend to be less aware of the value that information may have for them personally and that this lack of awareness may stem from their limited range of life experiences.

$\diamond$ That people find it difficult (and are variable in their ability) to assess their own informedness on a subject 
$\diamond$ That it is those that are most 'informed' that are most likely to be aware of both barriers to information and of personal disadvantage due to lack of information.

\section{REFERENCES}

Advisory Committee on Telematics for the Scottish Parliament (1997). A parliament for the new Millennium. Edinburgh: John Wheatley Centre.

Anderson, P. (2000). Partner libraries: the story so far. What's Happening in the Scottish Parliament, 48. http://www.scottish.parliament.uk/whats_happening/whisp-00/wh48-01.htm (visited September 2000).

Audunson, R. (1999). Can institutional theory contribute to our understanding of information seeking behaviour. In: Wilson, T.D. \& Allen, D.K., eds. Exploring the contexts of information behaviour: proceedings of the second International Conference on Research in Information Needs, Seeking and Use in different contexts, Sheffield University, $13-15$ August, 1998. London: Taylor Graham, 67-81.

Batt, C. (2000). The People's Network: the engine of the community. Library Technology, $5(4), 50-51$.

Beal, C. (1979). Studying the public's information needs. Journal of Librarianship, 11(2), 130-151.

Belkin, N. J. (1984). Cognitive models and information transfer. Social Science Information Studies, 4, 111-129.

Bettman, J. R. \& Pack, C. W. (1977). Effects of prior knowledge and experience and pace of the choice processes on consumer decision processes. Journal of Consumer Research, 3, 234-248.

Bichtler, J. \& Ward, D. (1989) . Information seeking behaviour of geoscientists. Special Libraries, 80(3), 169-178.

Blackshaw, L. \& Fischhoff, B. (1988). Decision making in online searching. Journal of the American Society for Information Science, 39(6), 369-389. 
Blair, T. (2000). Government to speed up introduction of online services. Press notice, 30 March. http://www.number-10.gov.uk/news.asp?NewsId=744\&SectionId=33 （visited September 2000).

Bruce, I., McKennel, A. \& Walker, E. (1991). Blind and partially sighted adults in Britain: the RNIB survey. London: RNIB.

Bystrom, K. (1999). Information seekers in context: an analysis of the 'doer' in INSU studies. In: Wilson, T.D. \& Allen, D.K., eds. Exploring the contexts of information behaviour: proceedings of the second International Conference on Research in Information Needs, Seeking and Use in different contexts, Sheffield University, 13 - 15 August, 1998. London: Taylor Graham, 82-95.

Cabinet Office (1998). Electronic government: the view from the queue. http://www.citu.gov.uk/research/viewqueue/ (visited March 1999).

Cabinet Office (1999). The future management of Crown Copyright. London: HMSO. (Cm 4300). http://www.hmso.gov.uk/document/copywp.htm (visited June 1999).

Cabinet Office (2000). e-government: a strategic framework for public services in the information age. http://www.citu.gov.uk/iagc/pdfs/Strategy.pdf (visited September 2000).

Campaign for Freedom of Information (1999). Deeply disappointing information bill weaker than Conservatives' openness code. Press release, 24 May. http://www/cfoi.org.uk/draftbill240599pr.html (visited June 1999).

Campaign for Freedom of Information (2001). Scottish information bill welcomed - with reservations. Press release, 1 March. http://www.cfoi.org.uk/scotdraftbill010301pr.html (visited June 2001).

Central Office of Information Informability Unit (1994). The informability guide. London: COI.

Coleman, S. (1999). Can the new media invigorate democracy? The Political Quarterly, 70(1), 16-22. 
Consultative Steering Group on the Scottish Parliament (1998a). Shaping Scotland's Parliament. Edinburgh: Scottish Office.

Consultative Steering Group on the Scottish Parliament (1998b). Information strategy for the Scottish Parliament. CSG Discussion Paper CSG(98)(77). http://www.scottishdevolution.org.uk/csg/csg77.htm (visited June 1999).

Consultative Steering Group on the Scottish Parliament (1998c). Information and communications technologies for the Scottish Parliament: current developments and future plans. [CSG Discussion Paper CSG (98)(90)]. http://www.scottishdevolution.org.uk/csg/csg90.htm (visited March 1999).

Dervin, B. (1976). The everyday information needs of the average citizen: a taxonomy for analysis. In: Kochen, M. \& Donohue, J.P., eds. Information for the community. Chicago: ALA, 19-38.

Dervin, B. (1977). Useful theory for librarianship: communication, not information. Drexel Library Quarterly, 13(3), 16-32.

Dervin, B. (1997). Given a context by any other name: methodological tools for taming the unruly beast. In: Vakkari, P., Savolainen, R. \& Dervin, B., eds. Information seeking in context. London: Taylor Graham, 13-38.

Dewar, D. (2000). First Minister pledges faster progress to electronic future. Press release, 31 March. http://www.scotland.gov.uk/news/2000/03/se0928.asp (visited September 2000).

Digital Scotland Task Force (2000). Digital Scotland Task Force report. http://www.scotland.gov.uk/digitalscotland/report.htm (visited September 2000).

Eager, C. \& Oppenheim, C. (1996). An observational method for undertaking user needs studies. Journal of Librarianship and Information Science, 28(1), 15-23.

Ecclestone, A. (1998). Freedom of Information and the Internet: an electronic window on to government. http://www.cfoi.org.uk/cyberwindow.html (visited March 1999).

Ellis, D. (1993). Modelling the information-seeking patterns of academic researchers: a grounded theory approach. Library Quarterly, 63(4), 471-486. 
Ellis, D., Cox, D. \& Hall, K. (1993). A comparison of the information seeking patterns of researchers in the physical and social sciences. Journal of Documentation, 49(4), 356-359.

Ericsson, K. A. \& Simon, H. A. (1993). Protocol analysis: verbal reports as data. Cambridge, MA: MIT Press.

Fee, J. (1999). Official Report (Hansard) of the Northern Ireland Assembly, 22 February, Line 300. http://www.ni-assembly.gov.uk/hansard.htm (visited September 2000).

Feick, L. F., Herrmann, R. O. \& Warland, R. H. (1986). Search for nutrition information: a probit analysis of the use of different information sources. Journal of Consumer Affairs, 20, 173-192.

Fishenden, R. M. (1965). Information use studies: Part 1 - past results and future needs. Journal of Documentation, 21(3), 163-169.

Folkman, S. (1984). Personal control and stress and coping processes: a theoretical analysis. Journal of Personality and Social Psychology, 46, 839-852. [As quoted by Wilson and Walsh, 1996.]

Ford, G. (1973). Research in user behaviour in university libraries. Journal of Documentation, 29(1), 85-106.

Ford, G. (1977). An introductory guide and select bibliography. Sheffield: Centre for Research on User Studies.

Great Britain: House of Commons (2000). Freedom of Information Act 2000. http://www.hmso.gov.uk/acts/acts2000/20000036.htm (visited June 2001).

Hallmark, J. (1994). Scientists' access and retrieval of references cited in their present journal articles. College and Research Libraries, 55(3), 201-209.

Hansard Society (1999). e-democracy programme. http://www.hansardsociety.org.uk/eDemocracy.htm (visited October 2001). 
Her Majesty's Stationery Office (2001). inforoute home page. http://www.hmso.gov.uk/inforoute/ (visited October 2001).

Hernon, P. \& Metoyer-Duran, C. (1992). Discussion forum: the public. Government Information Quarterly, 9(1), 1-10.

Hert, C. A. \& Marchionini, G. (1997). Seeking statistical information in Federal websites: users, tasks, strategies, and design recommendations. Final report to the Bureau of Labor Statistics. http://ils.unc.edu/ march/blsreport/blsmain.htm (visited March 1999).

Horner, J. \& Thirlwall, D. (1989). Online searching and the university researcher. Journal of Academic Librarianship, 14(4), 225-230.

House of Commons Information Office (2000). House of Commons Information Office annual report, 1 April 1999 - 31 March 2000. London: House of Commons Library.

House of Lords (2000). House of Lords annual report and accounts, 1999-2000. http://www.parliament.the-stationery-office.co.uk/pa/ld199900/ldbrief/10404.htm (visited January 2001).

Huber, G. P. (1983) . Cognitive-style as a basis for MIS and DSS designs: much ado about nothing. Management Science, 29(5), 567-579.

Jansen, B.J., Spink, A. \& Saracevic, T. (2000). Real life, real users and real need: a study and analysis of user queries on the web. Information Processing and Management, 36(2), 207227.

Kuhlthau, C. C. (1991). Inside the search process: information seeking from the user's perspective. Journal of the American Society for Information Science, 42, 361-371.

Kuhlthau, C. (1999). Investigating patterns in information seeking: concepts in context. In: Wilson, T.D. and Allen D.K., eds. Exploring the contexts of information behaviour: proceedings of the second International Conference on Research in Information Needs, Seeking and Use in different contexts, Sheffield University, 13 - 15 August, 1998. London: Taylor Graham, 10-20. 
Liberal Democrat Party (1998). Blair and Ashdown launch constitutional declaration. Press release, 11 June. Available from Liberal Democrats' press release archive at http://www.libdems.org.uk (visited June 1999).

Line, M. B. (1967). Library surveys. London: Bingley.

Line, M. B. (1971). The information uses and needs of social scientists: an overview of INFROSS. Aslib Proceedings, 23(8), 412-434.

Lipetz, B. (1970). Information needs and uses. In: Cuadra, C.A. \& Luke, A.W, eds. Annual review of information science and technology. Washington: American Society For Information Science, 3-32. [Volume 5]

Marcella, R. \& Baxter, G. (1998). Citizenship information, electronic government and social exclusion. Information UK Outlooks, whole issue.

Marcella, R. \& Baxter, G. (1999a). The information needs and the information seeking behaviour of a national sample of the population in the United Kingdom, with special reference to needs related to citizenship. Journal of Documentation, 55(2), 159-183.

Marcella, R. \& Baxter, G. (1999b). The citizenship information needs of the UK public: the quest for representativeness in methodological approach. In: Wilson, T.D. \& Allen, D.K., eds. Exploring the contexts of information behaviour: proceedings of the second Information Seeking in Context Conference, 13/15 August 1998, Sheffield. London: Taylor Graham, 304320.

Marcella, R. \& Baxter, G. (2000). Information need, information seeking behaviour and participation, with special reference to needs related to citizenship: results of a national survey. Journal of Documentation, 56(2), 136-160.

Marcella, R., Baxter, G. \& Parker, S. (1997). The provision of European information by public libraries in the UK: results of a British Library Research and Innovation Centre funded research project. Library Management, 18(1), 7-41.

Menzel, H. (1960). Review of studies of the flow of information among scientists. New York: Columbia University Bureau of Applied Social Research. [In two volumes] 
Moore, N. (1998). People and public services: a review of research into people's expectations and experiences of public services. London: The Cabinet Office and the Office for Public Management.

Nahl, D. \& Tenopir, C. (1996). Affective and cognitive searching behaviour of novice endusers of a full-text database. Journal of the American Society for Information Science, 47(4), 276-286.

National Assembly for Wales (2000). Agreement between the National Assembly for Wales and (name of local authority) on the establishment of Information Link. Unpublished, internal document, obtained in April 2001.

National Assembly for Wales (2001a). Home page. http://www.wales.gov.uk/ (visited October 2001).

National Assembly for Wales (2001b). Code of practice on public access to information. $2^{\text {nd }}$ edition. http://www.wales.gov.uk/keypubcodespractice/content/codespractice/contents-e.htm (visited June 2001).

National Working Party on Social Inclusion (1997). The Net result: social inclusion in the Information Society. London: IBM

Nicholas, D. (1996). An analysis of the online searching behaviour of practitioner end users. Journal of Documentation, 52(3), 227-251.

Northern Ireland Assembly (2001). Home page. http://www.ni-assembly.gov.uk/ (visited October 2001).

Paisley, W. J. (1965). The flow of (behavioural) science information: a review of the research literature. Palo Alto, Calif.: Stanford University.

Palmer, J. (1991). Scientists and information: I. Using cluster analysis to identify information style. Journal of Documentation, 47(2), 105-129.

Parliamentary Office of Science and Technology (1998). Electronic government: information technologies and the citizen. London: POST. 
Picton, H. (2001). Easier access to UK government information. Library Association Record, April 2001, 103(4), p.210.

Price, S. (1984). Information support for independent advice centres. Boston Spa: British Library Research and Development Department.

Radecki, C. M. \& Jaccard, J. (1995). Perceptions of knowledge, actual knowledge and information search behaviour. Journal of Experimental Social Psychology, 31, 107-138.

Saracevic, T. (1999). Information science. Journal of the American Society for Information Science, 50 (12), 1051-1063.

Saracevic, T., Mokros, H. \& Su, L. (1990). Nature of interaction between users and intermediaries in online searching. Proceedings of the American Society for Information Science, 27, 47-54.

Scottish Executive (1999). Code of practice on access to Scottish Executive information. http://www.scotland.gov.uk/library2/doc01/code.pdf (visited September 2000).

Scottish Executive (2000a). Information age government in Scotland: a draft common framework. http://www.scotland.gov.uk/government/c21g/iag-dcf.pdf (visited December 2000).

Scottish Executive (2000b). Digital Scotland: the way forward. The Scottish Executive's response to the report of the Digital Scotland Task Force. http://www.scotland.gov.uk/digitalscotland/seresponse.asp (visited September 2000).

Scottish Executive (2001). Freedom of information: consultation on draft legislation. http://www.scotland.gov.uk/consultations/government/dfib-00.asp (visited June 2001).

Scottish Library and Information Council and Scottish Library Association (2001). An open Scotland: freedom of information: a consultation. Response by Scottish Library and Information Council and Scottish Library Association. http://www.slainte.org.uk/Slicpubs/FreedomInfo.pdf (visited June 2001).

Scottish Parliament. (2001). Home page. http://www.scottish.parliament.uk/ (visited October 2001). 
Scottish Parliament Information Centre (2001). Partner Libraries telephone survey, February 2001. Unpublished document obtained from SPICe, March 2001.

Scottish Parliament Public Information Service (2001). Unpublished statistics obtained from Scottish Parliament Public Information Service, March 2001.

Shutz, A. (1946). The well informed citizen: an essay on the social distribution of knowledge. Social Research, 13, 463-478.

Steele, J. (1995). Public access to information: an evaluation of the Local Government (Access to Information) Act 1985. London: Policy Studies Institute and the Department of the Environment.

Streatfield, D.R. and Wilson, T.D. (1982). Information innovations in social services departments: a third report on Project INISS. Journal of Documentation, 38(4), 273-281.

Sturges, P. \& Chimseu, G. (1996). Qualitative research in information studies. Education for Information, 14, 117-126.

Taylor, R. (1987). On the study of information use environments. In: Hurd, J.M. \& Davis, C.H., eds. ASIS '86: Proceedings of the 49th ASIS Annual Meeting: Volume 23, Chicago, Illinois, September 28-October 2, 1986. Medford, New Jersey: Learned Information Inc. for the American Society for Information Science, 331-334.

Tinker, A., McCreadie, C. \& Salvage, A. (1994). The information needs of elderly people: an exploratory study. Assignation, 11(3), 44-46.

Trimble, D. (2000). Official Report (Hansard) of the Northern Ireland Assembly, 7 February, Line 588. http://www.ni-assembly.gov.uk/hansard.htm (visited September 2000).

UK Online (2001). Home page. http://www.ukonline.gov.uk/ (visited October 2001).

United Kingdom Parliament (2001). Home page. http://www.parliament.uk/ (visited October 2001). 
Vakkari, P. (1999). Task complexity, information types, search strategies and relevance: integrating studies on information seeking and retrieval. In: Wilson, T.D. \& Allen, D.K., eds. Exploring the contexts of information behaviour: proceedings of the second International Conference on Research in Information Needs, Seeking and Use in different contexts, Sheffield University, 13 - 15 August, 1998. London: Taylor Graham, 35-54.

Warner, E. S., Murray, A. D. \& Palmour, V. E. (1973). Information needs of urban residents. Washington, DC: US Department of Health, Education and Welfare; Office of Education; Bureau of Libraries and Learning Resources.

Weingand, D. (1993). Grounded theory and qualitative methodology. IFLA Journal, 19, 1726.

Wilson, T. D. (1981). On user studies and information needs. Journal of Documentation, 37(1), 3-15.

Wilson, T.D. (1994). Information needs and uses: fifty years of progress. In: Vickery, B.C., ed. Fifty years of information progress: a Journal of Documentation review. London: Aslib, $15-51$.

Wilson, T.D. (1999). Exploring models of information behaviour: the 'Uncertainty' Project. In: Wilson, T.D. \& Allen, D.K., eds. Exploring the contexts of information behaviour: proceedings of the second International Conference on Research in Information Needs, Seeking and Use in different contexts, Sheffield University, 13 - 15 August, 1998. London: Taylor Graham, 55-66.

Wilson, T.D. \& Streatfield, D.R. (1977). Information needs in local authority social services departments: an interim report on Project INISS. Journal of Documentation, 33(4), 277-293.

Wilson, T.D., Streatfield, D.R. \& Mullings, C. (1979). Information needs in local authority social services departments: a second report on Project INISS. Journal of Documentation, 35(2), 120-136.

Wilson, T. D. \& Walsh, C. (1996). Information behaviour: an interdisciplinary perspective. London: British Library Research and Innovation Centre. [BLR\&IC Report No. 10] 